\title{
КОНТРОЛЬНЫЕ ФУНКЦИИ РЕГИОНАЛЬНЫХ ОРГАНОВ ПО ПРОФИЛАКТИКЕ КОРРУПЦИИ
}

\begin{abstract}
Аннотация. Предметом проведенного исследования выступает правовое регулирование контрольных функций региональных органов по профилактике коррупции. Цель проведенного исследования - систематизация контрольных функций региональных органов по профилактике коррупции, анализ их содержания и выработка предложений по совершенствованию правового регулирования деятельности названных органов при осуществлении контроля. Задачи исследования:- раскрыть содержание контрольной функции региональных органов по профилактике коррупции; - выявить, описать и систематизировать основные виды контроля в сфере противодействия коррупции, осуществляемые этими органами; - определить основные формы государственного контроля, используемые региональными органами по профилактике коррупции; - осуществить анализ правового регулирования контроля, осуществляемого региональными органами по профилактике коррупции; - выработать предложения по совершенствованию правового регулирования и организации деятельности региональных органов по профилактике коррупции по осуществлению ими контроля в срере противодействия коррупции. Методологической основой проведенного исследования является диалектический материализм и основанные на нем общенаучные методы познания: анализ, синтез, сравнение и другие, используемые в юридических науках. Научная новизна проведенного исследования заключается в том, что автором впервые в юридической науке, на основе нормативных правовых актов, описываются и объясняются контрольные функции региональных органов по профилактике коррупции, описываются их основные виды и раскрывается их содержание, а также выделяются основные направления контрольной деятельности этих органов.
\end{abstract}

Ключевые слова: коррупция, противодействие коррупции, антикоррупционная политика, борьба с коррупцией, профилактика коррупции, правовое регулирование, антикоррупционный контроль, антикоррупционное законодательство, субъекты федерации, антикоррупционный орган.

Abstract. The research subject is legal regulation of the control functions of regional anti-corruption agencies. The purpose of the research is to systematize the control functions of regional anti-corruption agencies, to analyze their essence and to develop the proposals about the improvement of legal regulation of their activities. The study solves the following tasks:

- To reveal the essence of the control function of regional anti-corruption agencies;

- To detect, describe and systematize the main forms of control in the sphere of anti-corruption activities of these agencies;

- To define the main forms of public control, applied by regional anti-corruption agencies;

- To analyze legal regulation of control functions of regional anti-corruption agencies;

- To develop recommendations about the improvement of legal regulation and organization of anti-corruption control activities of regional anti-corruption agencies.

The research methodology is based on dialectical materialism and the relevant general scientific research methods: analysis, synthesis, comparison and other methods, used in the legal sciences. The scientific novelty consists in the analysis and explanation of the control functions of regional anti-corruption agencies, description of their main forms, essence and main directions of their control activities.

Key words: anti-corruption legislation, anti-corruption control, legal regulation, corruption prevention, struggle against corruption, anticorruption policy, anti-corruption, Corruption, constituent territories of the federation, anti-corruption agency. 


\section{Административное и муниципальное право 10 (106) 2016}

$\Pi$ ротиводействие коррупции в Российской Федерации - сложная и ответственная задача, решаемая различными государственными и общественными институтами, на различных уровнях и с различной степенью эффективности. При этом эффективная реализация противодействия коррупции невозможна без осуществления контроля за процессом и результатами её осуществления со стороны государственных органов и общественных институтов. Контрольными функциями по реализации государственной политики противодействия коррупции наделены различные субъекты её осуществления как на федеральном, так и на региональном и муниципальном уровнях. Контрольные и надзорные полномочия по реализации государственной политики противодействия коррупции, как правило, возлагаются различными по своей природе нормативными правовыми актами на органы государственной власти, органы местного самоуправления их должностных лиц и отдельные институты гражданского общества.

Обращаясь к региональным аспектам противодействия коррупции, следует отметить, что в числе таких государственных органов и должностных лиц, обладающих контрольными функциями по реализации государственной политики противодействия коррупции на региональном уровне, выступают:

a) высшие должностные лица (руководители высших исполнительных органов государственной власти) субъектов Российской Федерации;

б) региональные государственно-общественные совещательные, экспертные и координационные органы - комиссии по координации работы по противодействию коррупции в субъекте Российской Федерации;

в) региональные государственные органы - органы по профилактике коррупционных и иных правонарушений.

При этом комиссии по координации работы по противодействию коррупции в субъекте Российской Федерации и региональные органы по профилактике коррупционных и иных правонарушений, образуются в соответствии с Указом Президента Российской Федерации «0 мерах по совершенствованию организации деятельности в области противодействия коррупции» [41]. Хотя наименование этих органов, как и наименование и содержание их отдельных основных функций, могут быть различными.

В соответствии с федеральными нормативными правовыми актами в сфере противодействия коррупции, полномочия высших должностных лиц (руководителей высших исполнительных органов государственной власти) субъектов Российской
Федерации, как правило, сводятся к обеспечению контроля за исполнением региональных документов среднесрочного и/или краткосрочного планирования, подготовленных в соответствии с требованиями Национальной стратегии и Национального плана противодействия коррупции [42]. В отдельных федеральных нормативных актах предусмотрено обеспечение ими государственного контроля за применением мер юридической ответственности за неисполнение определенными лицами антикоррупционных обязанностей, ограничений, требований и запретов [43]. Механизмы и формы реализации обеспечения государственного и общественного контроля за исполнением положений федеральных и региональных нормативных правовых актов о противодействии коррупции связаны с деятельностью региональных органов по противодействию коррупции - комиссии по координации работы по противодействию коррупции и органа по профилактике коррупционных и иных правонарушений.

Необходимо отметить, что контрольные функции комиссий по координации работы по противодействию коррупции субъектов Российской Федерации, как правило, направлены лишь на обеспечение контроля за реализацией региональных документов среднесрочного и краткосрочного антикоррупционного планирования (региональной антикоррупционной программы и антикоррупционных программ органов исполнительной власти субъекта Российской Федерации либо планов противодействия коррупции).

Обратившись к правовому регулированию контрольных полномочий региональных органов по профилактике коррупционных и иных правонарушений, мы обнаружили, что они имеют разный правовой статус и именуются по-разному. В одних регионах они являются специализированными органами по противодействию коррупции, в других - частью государственных органов, выполняющими ряд других функций. Поэтому мы считаем для их функционального обозначения целесообразно использовать емкое словосочетание - «органы по профилактике коррупции» и дальше при исследовании все региональные органы по профилактике коррупционных и иных правонарушений именовать этим термином. Более того, в различных регионах антикоррупционные государственные органы обладают разными по объему и содержанию контрольными функциями и полномочиями, которые значительно шире, чем у комиссий по координации работы по противодействию коррупции в субъекте Российской Федерации.

Анализ нормативных правовых актов, регулирующих вопросы противодействия коррупции в российских регионах, показал, что размещение 
в этих документах контрольных функций органов по профилактике коррупции не отличается стройностью и последовательностью. Однако вопросы систематизации и унификации контрольных функций региональных органов по профилактике коррупционных и иных правонарушений, анализу их содержания и особенностям правового регулирования в современной юридической науке не поднимаются. Хотя о важности и необходимости государственного контроля в сфере противодействия коррупции отечественными специалистами отмечается давно [2, с.5-8; 3, с.2-6; 4, с. 9-12; 6, с.1623 ; 14 , с.67-74; 21 , c. $16-20 ; 22$, с.130-145; 27 , с.35-34; 28 , с. $51-73 ; 29$, с. $25-34 ; 34$, с.30-32; 79, с.126-134; 82, с.288-291; 88, с.15], а по отдельным направлениям государственного антикоррупционного контроля регулярно проводятся научные исследования и публикуются их результаты [7, с. 48-59; 18 , с. $60-$ $67 ; 19$, с. $146-151 ; 20$, с.85-90; 30, с. $32-35 ; 84$, с. 993996; 86, с. 3-5; 89, с.102-108; 92, с.83-98]. В связи с этим важным вопросом в сфере противодействия коррупции становится вопрос систематизации контрольных функций региональных органов по профилактике коррупции, анализ их содержания и выработка предложений по совершенствованию правового регулирования деятельности названных органов при организации и ими осуществлении государственного антикоррупционного контроля.

Описание и объяснение контрольных полномочий региональных органов по профилактике коррупции невозможно без обращения к научным работам по вопросам организации государственного контроля органами государственной власти таких российских специалистов как: Е.В. Авраамова [1], А.И. Гурин [13], Е.А. Маштакова [32], А.М. Тарасов [85], О.Е. Савенко [80], А.А. Джагарян [16], А.З. Завалунов [17], М.Л. Слепцов [83], В.Х. Махов [31], В.П. Уманская [87], Н.Н. Калюжный [23], Н.А. Даньшина [15] и другим [77ж 78]. В процессе проведения исследования автору пришлось обратиться и специальным работам по вопросам противодействия коррупции таких авторов как: В.В. Астанин [5], А.В. Куракин [24; 25], Н.И. Мельник [33], Б.В. Волженкин [8], Ю.В. Голик, В.И. Карасев [10], М.В. Шедий [90; 91] и другим [9].

Для описания и объяснения антикоррупционных контрольных функций региональных органов по профилактике коррупции мы проанализировали 468 действующих и утративших силу нормативных правовых актов, регулирующих антикоррупционную деятельность субъектов Российской Федерации, а также региональных государственных органов по профилактике коррупции. Результаты этого анализа и легли в основу данной работы.

Проведенный нами анализ нормативных правовых актов и научной литературы по вопросам противодействия коррупции и вопросам организации и осуществления государственного контроля в сфере противодействия коррупции в субъектах Российской Федерации позволяет утверждать, что такой контроль является необходимым средством (инструментом) гарантирующим качественную реализацию государственной политики противодействия коррупции на региональном уровне. Для региональных органов по профилактике коррупции контрольная функция является лишь одним из направлений их деятельности, и суть его сводится к проверке соответствия достигаемых результатов заявленным целям в сфере противодействия коррупции.

Основные контрольные функции региональных органов по профилактике коррупции закреплены в Типовом положении об органе субъекта Российской Федерации по профилактике коррупционных правонарушений (далее по тексту - Типовое положение - примечание автора - П.К.), утвержденного Указом Президента Российской Федерации «0 мерах по совершенствованию организации деятельности в области противодействия коррупции» [41]. В соответствии с ним можно выделить два вида контрольных функций - общие и специальные. Общими контрольными функциями региональных органов по профилактике коррупции можно считать - функции по контролю за организацией деятельности по противодействию коррупции юридическими лицами (органами государственной власти, органами местного самоуправления, учреждениями и организациями). Специальными контрольными функциями региональных органов по профилактике коррупции можно признавать контроль за отдельными направлениями антикоррупционной деятельности, осуществляемых органами государственной власти, органами местного самоуправления, учреждениями и организациями, предусмотренных нормативными правовыми актами, а также контроль за соблюдения лицами антикоррупционных запретов, требований, ограничений и обязанностей.

К общим контрольным функциям региональных органов по профилактике коррупции, предусмотренных Типовым положением, следует отнести три направления контрольной деятельности. Первое направление государственного контроля органов по профилактике коррупции это осуществление контроля за соблюдением законодательства Российской Федерации о противодействии коррупции в государственных учреждениях субъекта Российской Федерации. Второе направление - осуществление контроля за соблюдением законодательства Российской Федерации о противодействии коррупции в организациях, созданных для выполнения задач, поставленных 


\section{Административное и муниципальное право 10 (106) 2016}

перед органами исполнительной власти субъекта Российской Федерации. Третье направление - осуществление контроля за реализацией в названных учреждениях и организациях мер по профилактике коррупционных правонарушений. Все три направления взаимосвязаны между собой и подлежат дополнительному правовому регулированию. Для осуществления мер общего контроля за реализацией государственной политики противодействия коррупции юридическими лицами в субъекте Российской Федерации отдельные региональные органы государственной власти принимают нормативные правовые акты, регулирующие порядок его осуществления региональными органами по профилактике коррупции [74].

На наш взгляд, подобная практика правового регулирования осуществления региональными органами по профилактике коррупции государственного контроля за реализацией государственной политики противодействия коррупции в субъекте Российской Федерации является необходимой, заслуживающей одобрения и поддержки.

В соответствии с Типовым положением общий контроль региональных органов по профилактике коррупции за организацией и реализацией государственной политики противодействия коррупции в субъекте Российской Федерации касается только узкого круга объектов - государственных учреждений субъекта Российской Федерации и организаций, созданных для выполнения задач, поставленных перед органами исполнительной власти субъекта Российской Федерации. Хотя в Ненецком автономном округе на этот специальный антикоррупционный орган возлагается функция осуществления государственного контроля за соблюдением законодательства о противодействии коррупции Российской Федерации и Ненецкого автономного округа в исполнительных органах государственной власти автономного округа [73], тем самым изменен круг объектов государственного контроля за реализацией государственной политики противодействия коррупции. Вместо установленных федеральным нормативным правовым актом объектов государственного антикоррупционного контроля - государственных учреждений субъекта Российской Федерации и организаций, созданных для выполнения задач, поставленных перед органами исполнительной власти субъекта Российской Федерации органы государственной власти Ненецкого автономного округа включили другие объекты - исполнительные органы государственной власти автономного округа.

В отдельных субъектах Российской Федерации существует практика государственного контроля органов по профилактике коррупции за исполнением антикоррупционного законодатель- ства не только в органах исполнительной власти, государственных учреждений субъекта Российской Федерации и организаций, созданных для выполнения задач, поставленных перед органами исполнительной власти субъекта Российской Федерации, но и в муниципальных образованиях, органах местного самоуправления, муниципальных учреждениях и организациях [81, с.25-29]. На наш взгляд, такой широкий подход требует не только одобрения и поддержки, но и правового закрепления в региональном антикоррупционном законодательстве. В связи с этим считаем целесообразным расширение круга объектов общего государственного контроля за реализацией государственной политики противодействия коррупции, осуществляемых региональными органами по профилактике коррупции, дополнив перечень объектов государственного антикоррупционного контроля органами государственной власти, муниципальными образованиями и органами местного самоуправления, муниципальными организациями и учреждениями.

В некоторых субъектах Российской Федерации контрольные функции региональных органов по профилактике коррупции возлагаются без указания предмета антикоррупционной контрольной деятельности. Например, в Свердловской области на Администрацию Губернатора области - региональный орган по профилактике коррупции возложены контрольные функции, обеспечивающие деятельность губернатора в сфере противодействия коррупции [35]. В этом нормативном правовом акте трудно определить объект и предмет регионального государственного антикоррупционного контроля. Это не единственный случай, когда региональными нормативными правовыми актами не определяется структура антикоррупционной контрольной деятельности (объект, предмет, формы и методы государственного антикоррупционного контроля). Например, указом Губернатора Калининградской области на региональный орган по профилактике коррупции возложен государственный контроль за исполнением указов, распоряжений и поручений Президента Российской Федерации, региональных законов, нормативных актов и поручений высших должностных лиц субъекта Российской Федерации по вопросам противодействия коррупции [40]. В этом документе тоже отсутствуют структурные элементы контрольной деятельности регионального органа по профилактике коррупции, что может затруднить её осуществление в регионе.

На наш взгляд, в сложившейся ситуации для повышения эффективности контрольной функции региональных органов по профилактике коррупции необходимо во всех субъектах Российской 
Федерации принять региональные нормативные акты, регулирующих процедурные и технологические вопросы организации и осуществления общего государственного контроля за реализацией государственной политики противодействия коррупции.

К специальным контрольным функциям, закрепленных Типовым положением, следует отнести контрольную деятельность региональных органов по профилактике коррупции за реализацией органами, организациями и учреждениями отдельных направлений государственной политики противодействия коррупции. На наш взгляд, антикоррупционными контрольными функции, закрепленными не только Типовым положением, но и региональными нормативными правовыми актами являются следующие функции:

а) контроль за организацией антикоррупционного просвещения в государственных учреждениях субъекта Российской Федерации;

б) контроль за достоверностью и полнотой сведений об имущественном положении определенной категории должностных лиц и/или претендентов на эти должности в субъекте Российской Федерации:

- о доходах, об имуществе и обязательствах имущественного характера, предоставляемых гражданами, претендующими на замещение государственных должностей субъекта Российской Федерации и должностей государственной гражданской службы субъекта Российской Федерации;

- о доходах, расходах, об имуществе и обязательствах имущественного характера, представленных лицами, замещающими государственные должности субъекта Российской Федерации и государственными гражданскими служащими субъекта Российской Федерации [38; 72];

в) контроль за соблюдением лицами, замещающими государственные должности субъекта Российской Федерации и государственными гражданскими служащими субъекта Российской Федерации антикоррупционных запретов, обязанностей, ограничений и требований;

г) контроль за соблюдением гражданами, замещавшими должности государственной гражданской службы субъекта Российской Федерации, ограничений при заключении ими после увольнения с государственной гражданской службы субъекта Российской Федерации трудового договора и (или) гражданско-правового договора в случаях, предусмотренных федеральными законами.

Исследование контрольных функций региональных органов по профилактике коррупции оказалось бы не полным, если бы мы не обратились к региональному антикоррупционному законодательству. Анализ регионального антикоррупционного законодательства показал, что из всей совокупности действующих законов о противодействии коррупции субъектов Российской Федерации лишь в 15 имеется упоминание о контрольных функциях региональных органов по профилактике коррупции, как правило, с указанием лишь отдельных видов функций, осуществляемых ими. Хотя имеются и приятные исключения из этого правила. Например, в законе Пермского края «О противодействии коррупции в Пермском крае» имеется статья 13.2, которая дает полное описание контрольных функций органов государственной власти этого субъекта Российской Федерации, в том числе и органа по профилактике коррупции [55]. Следует отметить, что в этом региональном законе наиболее ценной частью выступает перечень основных направлений государственного контроля в сфере противодействия коррупции.

Рассматриваемая нами норма регионального антикоррупционного закона предусматривает контроль за выполнением органами государственной власти, учреждениями и организациями мероприятий, предусмотренных региональной антикоррупционной программой, планами по противодействию коррупции, и эффективностью принимаемых мер по противодействию коррупции, который можно назвать контролем за исполнением документов антикоррупционного планирования. Эта контрольная функция региональных органов по профилактике коррупции закреплена в региональном антикоррупционном законодательстве и других субъектов Российской Федерации - Удмуртской Республики [39] и Ульяновской области [63].

Упомянутой нормой рассматриваемого нами регионального закона предусмотрен государственный контроль органов по профилактике коррупции за исполнением органами государственной власти, учреждениями и организациями законодательства, регулирующего вопросы проведения антикоррупционной экспертизы региональных нормативных правовых актов и проектов региональных нормативных правовых актов. Это направление государственного контроля в сфере противодействия коррупции можно условно назвать контролем за организацией и осуществлением антикоррупционной экспертизы региональных нормативных правовых актов и проектов региональных нормативных правовых актов.

Государственный контроль со стороны региональных органов по профилактике коррупции Пермского края предусмотрен и по фактам обращений уполномоченных государственных органов, 


\section{Административное и муниципальное право 10 (106) • 2016}

граждан и юридических лиц в отношении наличия условий для проявления коррупции в деятельности государственных гражданских служащих. Это направление государственного контроля закреплено в антикоррупционном законодательстве и других субъектов Российской Федерации, но в иной интерпретации «контроль за решением вопросов, содержащихся в обращениях граждан и юридических лиц» $[49 ; 50 ; 52 ; 53 ; 54 ; 56 ; 57 ; 58 ; 59$; $60 ; 61 ; 62 ; 64]$. В представленном виде это направление государственного контроля не предусматривает его сущностного содержания - полнотой, всесторонностью и объективностью рассмотрения обращений и законностью принятия по ним решений, поэтому данная функция нуждается в уточнении. Представляется, что данную контрольную функцию регионального органа по профилактике коррупции следует именовать в соответствии с направлением контроля - контроль за полнотой, всесторонностью и объективностью рассмотрения обращений граждан и юридических лиц по вопросам противодействия коррупции и законностью принятия по ним решений.

Еще одним направлением контрольной деятельности регионального органа по профилактике коррупции, предусмотренных антикоррупционным законодательством Пермского края является осуществление контроля за принятием мер по выявлению и устранению причин и условий, способствующих возникновению конфликта интересов в органах государственной власти, учреждениях и организациях. В региональных нормативных актах других субъектов эта контрольная функция региональных органов по профилактике коррупции также присутствует [70].

Важнейшим направлением контрольной деятельности органа по профилактике коррупции Пермского края является осуществление им контроля за соблюдением порядка уведомления в целях склонения к совершению коррупционных правонарушений в органах государственной власти, учреждениях и организациях. Однако наименование этой контрольной функции представляется не вполне удачным, поскольку в федеральным законом «О противодействии коррупции» предписывается государственным или муниципальным служащим обязанность уведомлять представителя нанимателя (работодателя), органы прокуратуры или другие государственные органы обо всех случаях обращения к нему каких-либо лиц в целях склонения его к совершению коррупционных правонарушений [65]. Кроме того, обязанность уведомлять компетентные на то органы и должностных лиц возлагается и на другие категории работников, осуществляющих управленческие функции в государственных учреждениях и организациях [46; 75;
76] и/или иных лиц, наделенных властными полномочиями (лиц, замещающих государственные должности субъекта Российской Федерации [45] либо лиц, замещающих муниципальные должности и муниципальных служащих [36; 69]). Поэтому данную функцию целесообразнее назвать иначе функцией контроля за организацией исполнения в органах государственной власти, органах местного самоуправления, организациях и учреждениях государственными (муниципальными) служащими и иными лицами (работниками - примечание автора - П.К.) обязанности уведомлять представителя нанимателя (работодателя), органы прокуратуры или другие государственные органы обо всех случаях обращения к нему каких-либо лиц в целях склонения его к совершению коррупционных правонарушений.

В числе основных контрольных функций, возложенных законодателями на орган по профилактике коррупции Пермского края является обеспечение контроля за соблюдением порядка представления сведений о доходах, расходах, имуществе и обязательствах имущественного характера [55]. В тоже время в других субъектах Российской Федерации региональным антикоррупционным законодательством на эти органы чаще всего возлагается специальная функция контроля за соответствием расходов доходам различных категорий лиц, на которых возложены обязанности по предоставлению сведений о доходах и расходах [51].

Анализ антикоррупционного законодательства и иных нормативных правовых актов субъектов Российской Федерации позволяет нам обратить внимание на некоторые направления государственной политики противодействия коррупции, предусмотренные региональным антикоррупционным законодательством, остающиеся вне государственного контроля и которые можно без ущерба предоставить региональным органам по профилактике коррупции. В числе таких направлений государственной политики противодействия коррупции оказались:

а) организация и осуществление информационного обеспечения государственной политики противодействия коррупции;

б) организация и осуществление антикоррупционного образования;

в) организация взаимодействия органов государственной власти и органов местного самоуправления с институтами гражданского общества по вопросам противодействия коррупции;

г) организация и осуществление регионального антикоррупционного мониторинга.

Все четыре названных нами направления государственной политики противодействия корруп- 
ции являются важными и социально значимыми, поэтому нуждаются в контроле и надзоре за их организацией и качественным исполнением.

Следовательно, можно говорить о необходимости расширения предмета государственного контроля региональных органов по профилактике коррупции и дополнении их функциями по контролю в органах государственной власти, в органах местного самоуправления, в учреждениях и организациях по указанным выше направлениям деятельности.

Учитывая, что перечисленные нами выше направления деятельности, подлежащие государственному антикоррупционному контролю, обладают спецификой, требующий от должностных лиц контролирующих органов дополнительных знаний и навыков в области массовой коммуникации, в сферах образования и рекламной деятельности, которых они могут и не иметь, поэтому для обеспечения государственного контроля за их содержанием и качеством региональным органам по профилактике коррупции следует привлекать экспертов и экспертные учреждения в названных сферах деятельности и одновременно обладающих антикоррупционной компетентностью. Процедурные и технологические вопросы привлечения экспертов и экспертных учреждений к антикоррупционной деятельности следует предусмотреть в региональном нормативном правовом акте, регулирующем вопросы научного и/или экспертного сопровождения противодействия коррупции.

Важнейшей составляющей использования контрольной функции региональными органами по профилактике коррупции является обеспечение их необходимыми полномочиями и средствами обеспечения государственного контроля за реализацией государственной политики противодействия коррупции, закрепленных нормативными правовыми актами.

Необходимые полномочия по осуществлению оценки реального состояния дел о соблюдении антикоррупционных обязанностей, ограничений, запретов и требований определенными категориями лиц, а также исполнением антикоррупционного законодательства в органах, учреждениях и организациях и иных контрольных функций органов субъектов Российской Федерации по профилактике коррупции закреплены Типовым положением и региональными нормативными правовыми актами. Вне правового регулирования на федеральном уровне остаются формы осуществления государственного контроля за реализацией государственной политики противодействия коррупции региональными органами по профилактике коррупции. Однако региональные органы государственной власти начинают самостоятельно восполнять этот пробел правового регулирования. Например, в Ямало-Ненецком автономном округе постановлением губернатора закреплены такие формы государственного контроля за реализацией государственной политики противодействия коррупции как: а) плановая проверка; б) внеплановая проверка; в) документарная проверка; г) выездная проверка [74], фактически те же самые, что и предусмотренные федеральным законодательством о государственном (муниципальном) контроле [37]. К большому сожалению, о механизмах их осуществления имеется очень мало работ российских специалистов [25, с.16-19], что может привести к снижению эффективности их использования.

Следует иметь в виду, что формы осуществления государственного контроля региональными органами по профилактике коррупции в Типовом положении и иных нормативных правовых актах именуются по-разному. В одних случаях - осуществлением проверки (пп. «з» п.7 Типового положения), в других - проведением мониторинга (пп. «о» п.7 Типового положения), в третьих - анализом сведений (пп. «л» п.7 Типового положения). Для реализации этих форм государственного контроля за реализацией государственной политики противодействия коррупции высшие должностные лица субъектов Российской Федерации и органы исполнительной власти субъектов Российской Федерации уже принимают необходимые для этого нормативные правовые акты и/или изменяют и дополняют имеющиеся.

В настоящее время в российских регионах активно совершенствуются нормативные акты по следующим направлениям контрольной деятельности органов по профилактике коррупции:

- организации и осуществлению проверок в целях противодействия коррупции [44; 66; 67; 68; 71] (антикоррупционных проверок);

- проведению мониторинга деятельности по профилактике коррупционных и иных правонарушений в органах, организациях и учреждениях [47] (антикоррупционный мониторинг эффективности профилактики коррупции или мониторинг противодействия коррупции [11, с.145-148]);

- $\quad$ по анализу сведений о доходах, об имуществе и обязательствах имущественного характера определенной категории лиц [48] (антикоррупционный анализ имущественного состояния физических лиц).

Вместе с тем региональная практика, не ограничилась названными выше формами государственного антикоррупционного контроля, и выработала иные формы контроля за соблюдением антикоррупционного законодательства как юридическими, так и должностными лицами. В числе 


\section{Административное и муниципальное право 10 (106) 2016}

таких форм можно отметить антикоррупционную экспертизу нормативных правовых актов и проектов нормативных правовых актов, регулирующих вопросы организации и реализации государственной политики противодействия коррупции в регионе [12, с.45-47].

Ещё одной формой государственного контроля за реализацией государственной политики противодействия коррупции осуществляемой региональными органами по профилактике коррупции выступает заслушивание отчетов руководителей органов государственной власти, органов местного самоуправления, учреждений и организаций об эффективности реализации мер противодействия коррупции на совещаниях и иных мероприятиях проводимых этими органами. Эта форма наиболее часто проявляется в форме отчетов руководителей о выполнении ими положений ведомственных (муниципальных) или локальных планов по противодействию коррупции.

Проведенный нами анализ нормативных правовых актов по осуществлению региональными органами по профилактике коррупции контрольных функций позволяет сделать некоторые выводы.

Во-первых, государственный контроль за реализацией государственной политики противодействия коррупции в субъекте Российской Федерации - это одна из основных функций региональных органов по профилактике коррупции, суть которой сводится к проверке реального состояния дел при реализации мер противодействия коррупции на подконтрольном объекте.

Во-вторых, наделение полномочиями региональных органов по профилактике коррупции по осуществлению государственного контроля за результативностью реализации государственной политики противодействия коррупции в органах государственной власти, учреждениях и организациях не сопровождалось принятием необходимых региональных нормативных правовых актов по организации и осуществлению этими органами контрольных функций. Поэтому в ближайшее время органам государственной власти субъектов Российской Федерации необходимо принять нормативные правовые акты, регулирующие организацию и осуществление региональными органами по профилактике коррупции государственного контроля за реализацией государственной политики противодействия коррупции.

В-третьих, основными направлениями государственного контроля за реализацией государственной политики противодействия коррупции, осуществляемого региональными органами по профилактике коррупционных и иных правонарушений являются: а) исполнение документов регионального антикоррупционного планирования;

б) организация антикоррупционного просвещения;

в) организация и осуществление антикоррупционной экспертизы;

г) проверка полноты, всесторонности и объективности рассмотрения обращений граждан и юридических лиц по вопросам противодействия коррупции и законности принятия по ним решений;

д) принятие мер по выявлению и устранению причин и условий, способствующих возникновению конфликта интересов;

е) организация исполнения обязанности работников уведомлять о склонении их к совершению коррупционных правонарушений;

ж) организация соблюдения порядка представления сведений о доходах, расходах, имуществе и обязательствах имущественного характера;

и) соблюдение лицами, замещающими государственные должности субъекта Российской Федерации и государственными гражданскими служащими субъекта Российской Федерации антикоррупционных запретов, ограничений, обязанностей и требований;

к) соблюдение гражданами, замещавшими должности государственной гражданской службы субъекта Российской Федерации, ограничений при заключении ими после увольнения с государственной гражданской службы субъекта Российской Федерации трудового договора и (или) гражданско-правового договора в случаях, предусмотренных федеральными законодательством;

л) проверка достоверности и полноты сведений об имущественном положении определенной категории должностных лиц и/или претендентов на эти должности в субъекте Российской Федерации;

м) организация и осуществление информационного обеспечения государственной политики противодействия коррупции;

н) организация и качество антикоррупционного образования;

о) организация взаимодействия органов государственной власти и органов местного самоуправления с институтами гражданского общества в сфере противодействия коррупции.

В-четвертых, в целях систематизации и конкретизации контрольных функций региональных органов по профилактике коррупции, требуется правовое закрепление за ними этих функций в региональным антикоррупционном законодательстве либо подзаконных нормативных правовых актах, устанавливающих их правовое положение. 
Библиография:

1. Авраамова Е.В. Конституционно-правовое регулирование государственного контроля за осуществлением органами местного самоуправления отдельных государственных полномочий: автореф. дис. ... канд. юрид. наук. - М., 2012. -22 c.

2. Агеев В.Н. Государственный контроль за реализацией антикоррупционной политики в Российской Федерации // Актуальные проблемы экономики и права. - 2010. - № 4. - С.5-8.

3. Агеев В.Н., Агеева О.В. Государственный контроль за реализацией антикоррупционной политики в Российской Федерации: понятие и содержание // Следователь. - 2010. - № 12. - С.2-6.

4. Агеева О.В. Контроль за реализацией антикоррупционной политики на муниципальном уровне // Актуальные проблемы экономики и права. - 2010. - № 4. - С.9-12.

5. Астанин В.В. Антикоррупционная политика России. Криминологические аспекты: монография. - М., $2009 .-255$ с.

6. Братановский С.Н., Зеленов М.Ф. Конфликт интересов на государственной и муниципальной службе как объект антикоррупционного контроля // Государство и право. 2012. № 6. С. 16-23.

7. Вилчаева М.Н., Савоськин А.В. К вопросу о необходимости совершенствования законодательства о противодействии коррупции путем вменения контроля за расходами чиновников // Проблемы обеспечения, реализации, защиты конституционных прав и свобод человека. - 2014. - №3. - С.48-59.

8. Волженкин Б.В. Коррупция. - СПб., 1998. - 44 с.

9. Гарипов И.М. Виктимологические аспекты противодействия криминальному коррупционному поведению в Республике Татарстан/под науч. ред. д-ра юрид. наук П.А. Кабанова.-Казань, 2013. - 192 с.

10. Голик Ю.В., Карасев В.И. Коррупция как механизм социальной деградации. - СПб., 2005. - 329 с.

11. Горшенков А.Г., Горшенков Г.Н. Криминологический мониторинг противодействия коррупции // Актуальные проблемы экономики и права. 2010. № 2. С. 145-148.

12. Горшенков Г.Н. Коррупциогенные факторы антикоррупционных правовых актов // Актуальные проблемы экономики и права. 2009. № 4. С. 45-47.

13. Гурин А.И. Государственный контроль как форма осуществления исполнительной власти: дис. ... канд. юрид. наук. - Саратов, 2004. - 217 с

14. Гусельникова О.Ю. Конфликт интересов на муниципальной службе как объект антикоррупционного контроля // Экономика и менеджмент инновационных технологий. 2016. № 7 (58). С. 67-74.

15. Даньшина Н.А. Возможности и пределы государственного контпроля над жизнедеятельностью общества: автореф. дис. ... кандид. юрид. наук. - М., 2012. - 29 с.

16. Джагарян А.А. Конституционно-правовые основы государственного контроля в Российской Федерации. - М., 2008. - $176 \mathrm{c}$.

17. Завалунов А.З. Правовые основы государственного контроля в сфере исполнительной власти: автореф. дис. ... канд. юрид. наук. - М., 2009. - 29 с.

18. Зайков Д.Е. Правовое регулирование контроля за соответствием расходов работников их доходам в целях противодействия коррупции // Законодательство. - 2014. - №8. - С.60-67.

19. Зайцева Л.В. Контроль за доходами и расходами государственных гражданских служащих // Антикоррупционная политика государства: формирование и реализация в России и Германии: материалы Международной научно-практической конференции. - Тюмень, 2013. - С.146-151.

20. Зуева А.С. Предоставление сведений о расходах государственными служащими в зарубежных странах // Правовое поле современной экономики. - 2012. - №9. - С.85-90.

21. Кабанов П.А. Ведомственный контроль за реализацией антикоррупционной политики в субъектах Российской Федерации // Следователь. - 2011. - №9. - С.16-20.

22. Кабанов П.А. Организация и осуществление ведомственного контроля за реализацией государственной политики противодействия коррупции в регионах Российской Федерации // Юридические исследования. - 2014. № 6. - С.130-145

23. Калюжный Н.Н. Функция контроля в деятельности органов исполнительной власти Российской Федерации: дис. ... канд. юрид. наук. - М., 2003. - 241 с.

24. Куракин А.В. Административно-правовые средства предупреждения и пресечения коррупции в системе государственной службы Российской Федерации: монография. - М., 2005. - 214 с.

25. Куракин А.В. Государственная служба и коррупция: монография. - М., 2009. - 328 с.

26. Лаврентьева 0.0. Административная проверка как способ противодействия коррупции в системе государственной службы // Полицейская деятельность. 2012. № 3. С. 16-19.

27. Лаврентьева 0.О. Антикоррупционный контроль в системе государственной службы // Административное и муниципальное право. 2012. № 12. С. 35-43.

28. Лаврентьева 0.0. Контроль как способ противодействия коррупции в системе государственной службы // NB: Административное право и практика администрирования. 2014. № 4. С. 51-73.

29. Лаврентьева О.С. Контроль как способ противодействия коррупции в системе государственной службы Российской Федерации // Образование и право. - 2012. - № 11(39). - С.25-34.

30. Макаров А.В., Лютов В.А. К вопросу о контроле за соответствием расходов лиц, занимающих государственные должности, как одном из условий противодействия коррупции // Государственная власть и местное самоуправление. - 2014. - №4. - С.32-35.

31. Махов В.Х. Контрольные функции органов государственной власти Российской Федерации в условиях проведения административной реформы: автореф. дис. ... канд. юрид. наук. - М., 2005. - 23 с. 


\section{Административное и муниципальное право $10(106) \cdot 2016$}

32. Маштакова Е.А. Теоретико-правовые вопросы государственного контроля в Российской Федерации: дис. ... канд. юрид. наук. - Волгоград, 2000. - 205 с.

33. Мельник Н.И. Криминологические и уголовно-правовые проблемы противодействия коррупции: автореф. дис. ... д-ра юрид. наук. - Киев, 2002. - 32 с.

34. Михайлов В.И. Противодействие коррупции: на основе доверия и контроля // Государственная служба. - 2010. №6. - С.30-32.

35. О внесении изменений в Положение об Администрации Губернатора Свердловской области, утвержденное Указом Губернатора Свердловской области от 26.05.2004 №300-УГ: указ Губернатора Свердловской области от 01.10.2015 №444-УГ // Областная газета. - 2015. - 6 октября.

36. О внесении изменений в Положение об управлении государственной гражданской и муниципальной службы Нижегородской области, утвержденное постановлением Правительства Нижегородской области от 30 декабря 2014 года №951: постановление Правительства Нижегородской области от 01.10.2015 №622 // Нижегородские новости. - 2015. - 3 ноября.

37. О защите прав юридических лиц и индивидуальных предпринимателей при осуществлении государственного контроля (надзора) и муниципального контроля: федеральный закон от 26.12.2008 №294-Ф3 (в ред. от 03.07.2016 №354-Ф3) // Собрание законодательства РФ. - 2008. - №52 (ч. 1). - Ст. 6249.

38. О мерах по осуществлению контроля за соответствием расходов лиц, замещающих государственные должности, и иных лиц их доходам: постановление Губернатора Костромской области от 28.07.2015 №137 (в ред. от 16.04.2016 №69) // Официальный интернет-портал правовой информации www.pravo.gov.ru, 31.07.2015.

39. О мерах по противодействию коррупционным проявлениям в Удмуртской Республике: закон Удмуртской Республики от 20.09.2007 №55-Р3 (в ред. от 03.03.2016 №6-Р3) // Собрание законодательства Удмуртской Республики. - 2007. - №15.

40. 0 мерах по реализации пункта 2 Указа Президента Российской Федерации от 15 июля 2015 года №364 «0 мерах по совершенствованию организации деятельности в области противодействия коррупции»: указ Губернатора Калининградской области от 14.10.2015 №139 (в ред. от 05.04.2016 №42)// Официальный интернет-портал правовой информации http://www.pravo.gov.ru, 19.10.2015.

41. О мерах по совершенствованию организации деятельности в области противодействия коррупции: указ Президента Российской Федерации от 15 июля 2015 года №364 // Собрание законодательства РФ. - 2015. - №29 (часть II). - Ст.4477.

42. О Национальной стратегии противодействия коррупции и Национальном плане противодействия коррупции на 2010-2011 годы: указ Президента Российской Федерации от 13 апреля 2010 года №460 (в ред. от 13.03 .2012 №297) // Собрание законодательства РФ. - 2010. - №16. - Ст.1875.

43. О Национальном плане противодействия коррупции на 2016-2017 годы: указ Президента Российской Федерации от 1 апреля 2016 года №147 // Собрание законодательства РФ. - 2016. - №14. - Ст.1985.

44. О Порядке осуществления проверок в отношении отдельных категорий граждан в целях противодействия коррупции: указ Губернатора Иркутской области от 27.06.2013 №212-уг (в ред. от 31.10.2014 №334-уг) // Областная. - 2013. - 19 июля.

45. П Порядке уведомления лицами, замещающими отдельные государственные должности Орловской области, Губернатора Орловской области о фактах обращений к ним в целях склонения их к совершению коррупционных правонарушений и организации проверки сведений, содержащихся в уведомлениях: указ Губернатора Орловской области от 18.03.2015 №145 // Государственная специализированная информационная система "Портал Орловской области-публичный информационный центр" http://orel-region.ru, 19.03.2015.

46. О Порядке уведомления работодателя о фактах обращения в целях склонения работников организаций, находящихся в ведении Министерства внутренней политики, информации и связи Республики Крым, к совершению коррупционных правонарушений: приказ Министерства внутренней политики, информации и связи Республики Крым от 18.06.2015 №140;

47. О проведении мониторинга деятельности по профилактике коррупционных правонарушений в органах местного самоуправления в Республике Алтай, муниципальных организациях и учреждениях, а также соблюдения в них федерального законодательства и законодательства Республики Алтай о противодействии коррупции: распоряжение Главы Республики Алтай, Председателя Правительства Республики Алтай от 14.06.2016 №333-рГ // Официальный портал Республики Алтай http://www.altai-republic.ru, 14.06.2016.

48. О проверке достоверности и полноты сведений, представляемых гражданами, претендующими на замещение должностей государственной гражданской службы Архивной службы Кабардино-Балкарской Республики, и государственными гражданскими служащими Архивной службы Кабардино-Балкарской Республики, и соблюдения государственными гражданскими служащими Архивной службы Кабардино-Балкарской Республики требований к служебному поведению: приказ Архивной службы Кабардино-Балкарской Республики от 30.06 .2016 №50 // Официальная Кабардино-Балкария. - 2016. - 8 июля.

49. О противодействии коррупции в городе Севастополе: закон города Севастополя от 11.06.2014 №30-3С (в ред. от 04.05.2016 №243-3С) // Севастопольские известия. - 2014. - 18 июня.

50. О противодействии коррупции в Камчатском крае: закон Камчатского края от 18.12 .2008 №192 (в ред. от 01.04.2014 №404) // Официальные Ведомости. - 2008. - 30 декабря.

51. О противодействии коррупции в Кировской области: закон Кировской области от 30.04.2009 №365-30 (в ред. от 31.05.2016 №665-30) // Вятский край. - 2009. - 13 мая.

52. О противодействии коррупции в Краснодарском крае: закон Краснодарского края от 23.07.2009 №1798-КЗ (ред. от 06.11.2015 №3275-КЗ) // Кубанские новости. - 2009. - 6 августа. 
53. 0 противодействии коррупции в Курганской области: закон Курганской области от 03.03.2009 №439 (в ред. от 01.03.2016 №16) // Новый мир. - 2009. - 11 марта.

54. О противодействии коррупции в Орловской области: закон Орловской области от 10.04.2009 №893-03 (ред. от 24.12.2015 №1893-03) // Орловская правда. - 2009. - 18 апреля.

55. О противодействии коррупции в Пермском крае: закон Пермского края от 30.12.2008 №382-ПК (в ред. от 29.06.2016 №678-ПК) // Собрание законодательства Пермского края. - 2009. - №2 (II часть).

56. О противодействии коррупции в Республике Башкортостан: закон Республики Башкортостан от 13.07.2009 №145-3 (в ред. от 06.07.2012 №559-3) // Ведомости Государственного Собрания - Курултая, Президента и Правительства Республики Башкортостан. - 2009. - №17(311). - Ст.1087.

57. О противодействии коррупции в Республике Дагестан: закон Республики Дагестан от 07.04.2009 №21 (в ред. от 30.12.2013 №106) // Собрание законодательства Республики Дагестан. - 2009. - №7. - Ст.275.

58. О противодействии коррупции в Республике Калмыкия: закон Республики Калмыкия от 27.06.2008 №18-IV-3 (ред. от 20.11.2015 №156-V-3) // Хальмг Унн. - 2008. - 1 июля.

59. О противодействии коррупции в Республике Крым: закон Республики Крым от 22.07.2014 №36-3РК (ред. от 15.12.2014 №32-3РК/2014) // Крымские известия. - 2014. - 31 июля.

60. О противодействии коррупции в Республике Хакасия: Закон Республики Хакасия от 04.05.2009 №28-3РХ (в ред. от 05.02.2016 №07-3РХ) // Вестник Хакасии. - 2009. - 8 мая.

61. О противодействии коррупции в Ростовской области: областной закон Ростовской области от 12.05.2009 №218ЗС (ред. от 23.06.2016 №545-3С) // Наше время. - 2009. - 13 мая.

62. О противодействии коррупции в Самарской области: закон Самарской области от 10.03.2009 №23-ГД (в ред. от 19.05.2014 №57-ГД) // Волжская коммуна. - 2009. - 12 марта.

63. О противодействии коррупции в Ульяновской области: закон Ульяновской области от 20.07.2012 №89-30 (в ред. от 01.07.2016 №94-30) // Ульяновская правда. - 2012. - 24 июля.

64. О противодействии коррупции в Чеченской Республике: закон Чеченской Республики от 21 мая 2009 года №36Р3 (в ред. от 17.01.2016 №2-Р3) // Вести республики. - 2009. - 10 июня.

65. О противодействии коррупции: федеральный закон от 25.12.2008 №273-Ф3 (в ред. от 15.02.2016 №24-Ф3) // Собрание законодательства РФ. - 2008. - №52 (ч. 1). - Ст.6228.

66. О реализации законодательства о противодействии коррупции в отношении лиц, замещающих должности руководителей государственных учреждений Ярославской области: указ Губернатора Ярославской области от 28.02.2013 №111 (в ред. от 07.04.2016 №185) // Документ-Регион. - 2013. - 5 марта.

67. реализации законодательства о противодействии коррупции в отношении лиц, замещающих государственные должности Ярославской области: указ Губернатора Ярославской области от 31.01.2013 №46 (в ред. от 07.04.2016 №185) // Документ-Регион. - 2013. - 12 февраля.

68. О создании рабочей группы по проведению выборочных выездных проверок деятельности органов местного самоуправления Республики Калмыкия по противодействию коррупции: распоряжение Главы Республики Калмыкия от 24.09.2010 №171-рг (в ред. от 19.12.2011 №231-рг) // Хальмг унн. - 2010. - 29 сентября.

69. Об управлении кадровой политики и противодействия коррупции администрации Краснодарского края: постановление главы администрации (губернатора) Краснодарского края от 21.12.2015 №1243 (в ред. от 16.05 .2016 №310)// Официальный сайт администрации Краснодарского края http://admkrai.krasnodar.ru, 21.12.2015.

70. Об утверждении Положения о Департаменте общественной безопасности города Севастополя: постановление Правительства Севастополя от 13.09.2016 №859-ПП // Официальный сайт Правительства Севастополя http:// sevastopol.gov.ru, 14.09.2016.

71. Об утверждении положения о порядке проведения проверки, предусмотренной частью 6 статьи 12 Федерального закона от 25 декабря 2008 года №273-Ф3 "О противодействии коррупции": приказ минэкономики Нижегородской области от 11.04.2016 №79 // Нижегородская правда. - 2016. - 2 июля.

72. Об утверждении Положения о проверке достоверности и полноты сведений о доходах, об имуществе и обязательствах имущественного характера, представляемых гражданами, претендующими на замещение государственных должностей Республики Мордовия, и лицами, замещающими государственные должности Республики Мордовия, и соблюдения ограничений лицами, замещающими государственные должности Республики Мордовия: указ Главы Республики Мордовия от 05.02.2016 №27-УГ // Известия Мордовии. - 2016. - 9 февраля;

73. Об утверждении положения об отделе противодействия коррупции управления государственной гражданской службы и кадров Аппарата Администрации Ненецкого автономного округа: приказ Аппарата администрации Ненецкого автономного округа от 30.12.2014 №92.

74. Об утверждении Порядка осуществления контроля за соблюдением законодательства Российской Федерации о противодействии коррупции в государственных учреждениях Ямало-Ненецкого автономного округа и организациях, созданных для выполнения задач, поставленных перед исполнительными органами государственной власти Ямало-Ненецкого автономного округа, а также за реализацией в этих учреждениях и организациях мер по профилактике коррупционных правонарушений: постановление Губернатора Ямало-Ненецкого автономного округа от 07.04.2016 №63-ПГ // Красный Север. - 2016. - 15 апреля.

75. Об утверждении Порядка уведомления работодателя о фактах обращения в целях склонения работника Государственного учреждения-Пермского регионального отделения Фонда социального страхования Российской Федерации к совершению коррупционных правонарушений, регистрации таких уведомлений и организации проверки содержащихся в них сведений: приказ ГУ-Пермского регионального отделения ФСС РФ от 15.01.2013 №16;

76. б утверждении порядка уведомления работодателя о фактах обращения в целях склонения работника, занимающего должность, не относящуюся к должностям муниципальной службы, муниципальным должностям администрации городского поселения Красногорск, к совершению коррупционных правонарушений: распоряже- 
ние главы городского поселения Красногорск Красногорского муниципального района Московской области от 09.02.2016 №27 // Красногорские вести. - 2016. - 22 марта.

77. Правовое регулирование государственного контроля: монография / отв. ред. А.Ф. Ноздрачев. - М., $2012 .-480$ с.

78. Правовой механизм государственного контроля и надзора: особенности отраслевого регулирования: монография / Под общ. ред. О.Ю. Бакаева. - М., 2013. - 256 с.

79. Противодействие коррупции в субъектах Российской Федерации: научно-практическое пособие / Л.В. Андриченко, О.А. Беляева, В.И. Васильев и др.; под ред. Т.Я. Хабриевой. - М., 2013. - 236 с.

80. Савенко О.Е. Контрольная функция государственных органов: дис. ... канд. юрид. наук. - Саратов, 2004. - 195 с.

81. Сводный отчет о состоянии коррупции и реализации мер антикоррупционной политики в Республике Татарстан в 2013 году. - Казань, 2004. - 126 с.

82. Симбирёва Е.В. Антикоррупционный контроль в системе государственной службы // Модернизационный вектор развития науки в XXI веке: традиции, новации, преемственность сборник научных статей по итогам международной научно-практической конференции. СПб., 2016. С. 288-291.

83. Слепцов М.Г. Правовое регулирование государственного контроля в краях и областях - субъектах Российской Федерации: автореф. дис. ... канд. юрид. наук. - М., 1999.

84. Соловьева Е.П., Цыбаков Д.Л. Контроль за расходами государственных служащих как инструмент противодействия коррупции // Экономика и социум. - 2014. - №4-4 (13). - С.993-996.

85. Тарасов А.М. Государственный контроль в России: монография. - М., 2008. - 644 с.

86. Улизько К.А. Контроль имущественного положения лиц, замещающих (занимающих) должности, установленных законодательством о противодействии коррупции // Муниципальная служба: правовые вопросы. - 2016. №2. - C.3-5.

87. Уманская В.П. Государственный контроль и надзор за соблюдением законодательства о государственной гражданской службе: автореф. дис. ... канд. юрид. наук. - М., 2007. - 18 с.

88. Х Хабриева Т.Я. Коррупция и право: доктринальные подходы к постановке проблемы // Журнал российского права. - 2012.-№6. - C.5-17.

89. Чаннов С.Е. Закон о контроле за расходами чиновников: вопросы эффективности // Государственный аудит. Право. Экономика. - 2013. - №2. - С.102-108.

90. Шедий М.В. Коррупция как социальное явление: теоретико-методологические аспекты исследования: Монография. - Орел, 2011. - 180 с.

91. Шедий М.В. Социальные детерминанты коррупции в российском обществе: Монография. - Орел, $2012 .-148$ с.

92. Шуруханова Д.Н. Контроль имущественного положения как мера по противодействию коррупции // NB: Административное право и практика администрирования. - 2013. - №6. - С.83-98.

93. Бикеев И.И., Магизов Р.Р. Рецензия на монографию: Кабанов П.А. Антикоррупционный мониторинг в субъектах Российской Федерации: вопросы теории и практики правового регулирования. - Нижний Новгород: Нижегородская академия МВД России, 2015. - 181 с. // NB: Административное право и практика администрирования. 2016. - 3. - C. 26 - 39. DOI: 10.7256/2306-9945.2016.3.19010. URL: http://www.e-notabene.ru/al/article_19010.html

\section{References (transliterated):}

1. Avraamova E.V. Konstitutsionno-pravovoe regulirovanie gosudarstvennogo kontrolya za osushchestvleniem organami mestnogo samoupravleniya otdel'nykh gosudarstvennykh polnomochii: avtoref. dis. ... kand. yurid. nauk. - M., 2012 . - $22 \mathrm{~s}$.

2. Ageev V.N. Gosudarstvennyi kontrol' za realizatsiei antikorruptsionnoi politiki v Rossiiskoi Federatsii // Aktual'nye problemy ekonomiki i prava. - 2010. - № 4. - S.5-8.

3. Ageev V.N., Ageeva O.V. Gosudarstvennyi kontrol' za realizatsiei antikorruptsionnoi politiki v Rossiiskoi Federatsii: ponyatie i soderzhanie // Sledovatel'. - 2010. - № 12. - S.2-6.

4. Ageeva O.V. Kontrol' za realizatsiei antikorruptsionnoi politiki na munitsipal'nom urovne // Aktual'nye problemy ekonomiki i prava. - 2010. - № 4. - S.9-12.

5. Astanin V.V. Antikorruptsionnaya politika Rossii. Kriminologicheskie aspekty: monografiya. - M., $2009 .-255$ s.

6. Bratanovskii S.N., Zelenov M.F. Konflikt interesov na gosudarstvennoi i munitsipal'noi sluzhbe kak ob"'ekt antikorruptsionnogo kontrolya // Gosudarstvo i pravo. 2012. № 6. S. 16-23.

7. Vilchaeva M.N., Savos'kin A.V. K voprosu o neobkhodimosti sovershenstvovaniya zakonodatel'stva o protivodeistvii korruptsii putem vmeneniya kontrolya za raskhodami chinovnikov // Problemy obespecheniya, realizatsii, zashchity konstitutsionnykh prav i svobod cheloveka. - 2014. - №3. - S.48-59.

8. Volzhenkin B.V. Korruptsiya. - SPb., 1998. - 44 s.

9. Garipov I.M. Viktimologicheskie aspekty protivodeistviya kriminal'nomu korruptsionnomu povedeniyu v Respublike Tatarstan/pod nauch. red. d-ra yurid. nauk P.A. Kabanova.-Kazan', 2013. - $192 \mathrm{~s}$.

10. Golik Yu.V., Karasev V.I. Korruptsiya kak mekhanizm sotsial'noi degradatsii. - SPb., 2005. - $329 \mathrm{~s}$

11. Gorshenkov A.G., Gorshenkov G.N. Kriminologicheskii monitoring protivodeistviya korruptsii // Aktual'nye problemy ekonomiki i prava. 2010. № 2. S. 145-148.

12. Gorshenkov G.N. Korruptsiogennye faktory antikorruptsionnykh pravovykh aktov // Aktual'nye problemy ekonomiki i prava. 2009. № 4. S. 45-47.

13. Gurin A.I. Gosudarstvennyi kontrol' kak forma osushchestvleniya ispolnitel'noi vlasti: dis. ... kand. yurid. nauk. - Saratov, 2004. - $217 \mathrm{~s}$.

14. Gusel'nikova O.Yu. Konflikt interesov na munitsipal'noi sluzhbe kak ob"ekt antikorruptsionnogo kontrolya // Ekonomika i menedzhment innovatsionnykh tekhnologii. 2016. № 7 (58). S. 67-74.

15. Dan'shina N.A. Vozmozhnosti i predely gosudarstvennogo kontprolya nad zhiznedeyatel'nost'yu obshchestva: avtoref. dis. ... kandid. yurid. nauk. - M., 2012. - 29 s. 
16. Dzhagaryan A.A. Konstitutsionno-pravovye osnovy gosudarstvennogo kontrolya v Rossiiskoi Federatsii. - M., 2008. - 176 s.

17. Zavalunov A.Z. Pravovye osnovy gosudarstvennogo kontrolya v sfere ispolnitel'noi vlasti: avtoref. dis. ... kand. yurid. nauk. - M., 2009. - 29 s.

18. Zaikov D.E. Pravovoe regulirovanie kontrolya za sootvetstviem raskhodov rabotnikov ikh dokhodam $\mathrm{v}$ tselyakh protivodeistviya korruptsii // Zakonodatel'stvo. - 2014. - №8. - S.60-67.

19. Zaitseva L.V. Kontrol' za dokhodami i raskhodami gosudarstvennykh grazhdanskikh sluzhashchikh // Antikorruptsionnaya politika gosudarstva: formirovanie i realizatsiya v Rossii i Germanii: materialy Mezhdunarodnoi nauchno-prakticheskoi konferentsii. - Tyumen', 2013. - S.146-151.

20. Zueva A.S. Predostavlenie svedenii o raskhodakh gosudarstvennymi sluzhashchimi v zarubezhnykh stranakh // Pravovoe pole sovremennoi ekonomiki. - 2012. - №9. - S.85-90.

21. Kabanov P.A. Vedomstvennyi kontrol' za realizatsiei antikorruptsionnoi politiki v sub"ektakh Rossiiskoi Federatsii // Sledovatel'. - 2011. - №9. - S.16-20.

22. Kabanov P.A. Organizatsiya i osushchestvlenie vedomstvennogo kontrolya za realizatsiei gosudarstvennoi politiki protivodeistviya korruptsii v regionakh Rossiiskoi Federatsii // Yuridicheskie issledovaniya. - 2014. - № 6. - S.130-145.

23. Kalyuzhnyi N.N. Funktsiya kontrolya v deyatel'nosti organov ispolnitel'noi vlasti Rossiiskoi Federatsii: dis. ... kand. yurid. nauk. - M., 2003. - 241 s.

24. Kurakin A.V. Administrativno-pravovye sredstva preduprezhdeniya i presecheniya korruptsii v sisteme gosudarstvennoi sluzhby Rossiiskoi Federatsii: monografiya. - M., 2005. - 214 s.

25. Kurakin A.V. Gosudarstvennaya sluzhba i korruptsiya: monografiya. - M., 2009. - 328 s.

26. Lavrent'eva 0.0. Administrativnaya proverka kak sposob protivodeistviya korruptsii v sisteme gosudarstvennoi sluzhby // Politseiskaya deyatel'nost'. 2012. № 3. S. 16-19.

27. Lavrent'eva 0.0. Antikorruptsionnyi kontrol' v sisteme gosudarstvennoi sluzhby // Administrativnoe i munitsipal'noe pravo. 2012. № 12. S. 35-43.

28. Lavrent'eva 0.0. Kontrol' kak sposob protivodeistviya korruptsii $\mathrm{v}$ sisteme gosudarstvennoi sluzhby // NB: Administrativnoe pravo i praktika administrirovaniya. 2014. № 4. S. 51-73.

29. Lavrent'eva O.S. Kontrol' kak sposob protivodeistviya korruptsii v sisteme gosudarstvennoi sluzhby Rossiiskoi Federatsii // Obrazovanie i pravo. - 2012. - № 11(39). - S.25-34.

30. Makarov A.V., Lyutov V.A. K voprosu o kontrole za sootvetstviem raskhodov lits, zanimayushchikh gosudarstvennye dolzhnosti, kak odnom iz uslovii protivodeistviya korruptsii // Gosudarstvennaya vlast' i mestnoe samoupravlenie. 2014. - №4. - S.32-35.

31. Makhov V.Kh. Kontrol'nye funktsii organov gosudarstvennoi vlasti Rossiiskoi Federatsii v usloviyakh provedeniya administrativnoi reformy: avtoref. dis. ... kand. yurid. nauk. - M., 2005. - 23 s.

32. Mashtakova E.A. Teoretiko-pravovye voprosy gosudarstvennogo kontrolya v Rossiiskoi Federatsii: dis. ... kand. yurid. nauk. - Volgograd, 2000. - 205 s.

33. Mel'nik N.I. Kriminologicheskie i ugolovno-pravovye problemy protivodeistviya korruptsii: avtoref. dis. ... d-ra yurid. nauk. - Kiev, 2002. - 32 s.

34. Mikhailov V.I. Protivodeistvie korruptsii: na osnove doveriya i kontrolya // Gosudarstvennaya sluzhba. - 2010. - №6. S.30-32.

35. O vnesenii izmenenii v Polozhenie ob Administratsii Gubernatora Sverdlovskoi oblasti, utverzhdennoe Ukazom Gubernatora Sverdlovskoi oblasti ot 26.05.2004 №300-UG: ukaz Gubernatora Sverdlovskoi oblasti ot 01.10.2015 №444UG // Oblastnaya gazeta. - 2015. - 6 oktyabrya.

36. O vnesenii izmenenii v Polozhenie ob upravlenii gosudarstvennoi grazhdanskoi i munitsipal'noi sluzhby Nizhegorodskoi oblasti, utverzhdennoe postanovleniem Pravitel'stva Nizhegorodskoi oblasti ot 30 dekabrya 2014 goda №951: postanovlenie Pravitel'stva Nizhegorodskoi oblasti ot 01.10.2015 №622 // Nizhegorodskie novosti. - 2015. - 3 noyabrya.

37. O zashchite prav yuridicheskikh lits i individual'nykh predprinimatelei pri osushchestvlenii gosudarstvennogo kontrolya (nadzora) i munitsipal'nogo kontrolya: federal'nyi zakon ot 26.12.2008 №294-FZ (v red. ot 03.07.2016 №354-FZ) // Sobranie zakonodatel'stva RF. - 2008. - №52 (ch. 1). - St. 6249.

38. O merakh po osushchestvleniyu kontrolya za sootvetstviem raskhodov lits, zameshchayushchikh gosudarstvennye dolzhnosti, i inykh lits ikh dokhodam: postanovlenie Gubernatora Kostromskoi oblasti ot 28.07.2015 №137 (v red. ot 16.04.2016 №69) // Ofitsial'nyi internet-portal pravovoi informatsii www.pravo.gov.ru, 31.07.2015.

39. O merakh po protivodeistviyu korruptsionnym proyavleniyam v Udmurtskoi Respublike: zakon Udmurtskoi Respubliki ot 20.09.2007 №55-RZ (v red. ot 03.03.2016 №6-RZ) // Sobranie zakonodatel'stva Udmurtskoi Respubliki. - 2007. - №15.

40. 0 merakh po realizatsii punkta 2 Ukaza Prezidenta Rossiiskoi Federatsii ot 15 iyulya 2015 goda №364 «0 merakh po sovershenstvovaniyu organizatsii deyatel'nosti v oblasti protivodeistviya korruptsii»: ukaz Gubernatora Kaliningradskoi oblasti ot 14.10.2015 №139 (v red. ot 05.04.2016 №42)// Ofitsial'nyi internet-portal pravovoi informatsii http://www. pravo.gov.ru, 19.10.2015.

41. O merakh po sovershenstvovaniyu organizatsii deyatel'nosti v oblasti protivodeistviya korruptsii: ukaz Prezidenta Rossiiskoi Federatsii ot 15 iyulya 2015 goda №364 // Sobranie zakonodatel'stva RF. - 2015. - №29 (chast' II). - St.4477.

42. O Natsional'noi strategii protivodeistviya korruptsii i Natsional'nom plane protivodeistviya korruptsii na 2010-2011 gody: ukaz Prezidenta Rossiiskoi Federatsii ot 13 aprelya 2010 goda №460 (v red. ot 13.03.2012 №297) // Sobranie zakonodatel'stva RF. - 2010. - №16. - St.1875.

43. O Natsional'nom plane protivodeistviya korruptsii na 2016-2017 gody: ukaz Prezidenta Rossiiskoi Federatsii ot 1 aprelya 2016 goda №147 // Sobranie zakonodatel'stva RF. - 2016. - №14. - St.1985.

44. O Poryadke osushchestvleniya proverok $v$ otnoshenii otdel'nykh kategorii grazhdan v tselyakh protivodeistviya korruptsii: ukaz Gubernatora Irkutskoi oblasti ot 27.06.2013 №212-ug (v red. ot 31.10.2014 №334-ug) // Oblastnaya. - 2013. 19 iyulya. 


\section{Административное и муниципальное право $10(106) \cdot 2016$}

45. O Poryadke uvedomleniya litsami, zameshchayushchimi otdel'nye gosudarstvennye dolzhnosti Orlovskoi oblasti, Gubernatora Orlovskoi oblasti o faktakh obrashchenii k nim v tselyakh skloneniya ikh k soversheniyu korruptsionnykh pravonarushenii i organizatsii proverki svedenii, soderzhashchikhsya v uvedomleniyakh: ukaz Gubernatora Orlovskoi oblasti ot 18.03.2015 №145 // Gosudarstvennaya spetsializirovannaya informatsionnaya sistema "Portal Orlovskoi oblasti-publichnyi informatsionnyi tsentr" http://orel-region.ru, 19.03.2015.

46. O Poryadke uvedomleniya rabotodatelya o faktakh obrashcheniya $\mathrm{v}$ tselyakh skloneniya rabotnikov organizatsii, nakhodyashchikhsya v vedenii Ministerstva vnutrennei politiki, informatsii i svyazi Respubliki Krym, k soversheniyu korruptsionnykh pravonarushenii: prikaz Ministerstva vnutrennei politiki, informatsii i svyazi Respubliki Krym ot 18.06.2015 №140;

47. O provedenii monitoringa deyatel'nosti po profilaktike korruptsionnykh pravonarushenii $\mathrm{v}$ organakh mestnogo samoupravleniya $v$ Respublike Altai, munitsipal'nykh organizatsiyakh i uchrezhdeniyakh, a takzhe soblyudeniya v nikh federal'nogo zakonodatel'stva i zakonodatel'stva Respubliki Altai o protivodeistvii korruptsii: rasporyazhenie Glavy Respubliki Altai, Predsedatelya Pravitel'stva Respubliki Altai ot 14.06.2016 №333-rG // Ofitsial'nyi portal Respubliki Altai http://www.altai-republic.ru, 14.06.2016.

48. O proverke dostovernosti i polnoty svedenii, predstavlyaemykh grazhdanami, pretenduyushchimi na zameshchenie dolzhnostei gosudarstvennoi grazhdanskoi sluzhby Arkhivnoi sluzhby Kabardino-Balkarskoi Respubliki, i gosudarstvennymi grazhdanskimi sluzhashchimi Arkhivnoi sluzhby Kabardino-Balkarskoi Respubliki, i soblyudeniya gosudarstvennymi grazhdanskimi sluzhashchimi Arkhivnoi sluzhby Kabardino-Balkarskoi Respubliki trebovanii k sluzhebnomu povedeniyu: prikaz Arkhivnoi sluzhby Kabardino-Balkarskoi Respubliki ot 30.06.2016 №50 // Ofitsial'naya Kabardino-Balkariya. - 2016. - 8 iyulya.

49. O protivodeistvii korruptsii v gorode Sevastopole: zakon goroda Sevastopolya ot 11.06.2014 №30-ZS (v red. ot 04.05.2016 №243-ZS) // Sevastopol'skie izvestiya. - 2014. - 18 iyunya.

50. O protivodeistvii korruptsii v Kamchatskom krae: zakon Kamchatskogo kraya ot 18.12.2008 №192 (v red. ot 01.04 .2014 №404) // Ofitsial'nye Vedomosti. - 2008. - 30 dekabrya.

51. O protivodeistvii korruptsii v Kirovskoi oblasti: zakon Kirovskoi oblasti ot 30.04.2009 №365-Z0 (v red. ot 31.05.2016 №665-ZO) // Vyatskii krai. - 2009. - 13 maya.

52. O protivodeistvii korruptsii v Krasnodarskom krae: zakon Krasnodarskogo kraya ot 23.07.2009 №1798-KZ (red. ot 06.11.2015 №3275-KZ) // Kubanskie novosti. - 2009. - 6 avgusta.

53. O protivodeistvii korruptsii v Kurganskoi oblasti: zakon Kurganskoi oblasti ot 03.03.2009 №439 (v red. ot 01.03 .2016 №16) // Novyi mir. - 2009. - 11 marta.

54. O protivodeistvii korruptsii v Orlovskoi oblasti: zakon Orlovskoi oblasti ot 10.04.2009 №893-0Z (red. ot 24.12.2015 №1893-OZ) // Orlovskaya pravda. - 2009. - 18 aprelya.

55. O protivodeistvii korruptsii v Permskom krae: zakon Permskogo kraya ot 30.12.2008 №382-PK (v red. ot 29.06.2016 №678-PK) // Sobranie zakonodatel'stva Permskogo kraya. - 2009. - №2 (II chast').

56. O protivodeistvii korruptsii v Respublike Bashkortostan: zakon Respubliki Bashkortostan ot 13.07.2009 №145-z (v red. ot 06.07.2012 №559-z) // Vedomosti Gosudarstvennogo Sobraniya - Kurultaya, Prezidenta i Pravitel'stva Respubliki Bashkortostan. - 2009. - №17(311). - St.1087.

57. O protivodeistvii korruptsii v Respublike Dagestan: zakon Respubliki Dagestan ot 07.04.2009 №21 (v red. ot 30.12 .2013 №106) // Sobranie zakonodatel'stva Respubliki Dagestan. - 2009. - №7. - St.275.

58. O protivodeistvii korruptsii v Respublike Kalmykiya: zakon Respubliki Kalmykiya ot 27.06.2008 №18-IV-Z (red. ot 20.11.2015 №156-V-Z) // Khal'mg Unn. - 2008. - 1 iyulya.

59. O protivodeistvii korruptsii v Respublike Krym: zakon Respubliki Krym ot 22.07.2014 №36-ZRK (red. ot 15.12.2014 №32-ZRK/2014) // Krymskie izvestiya. - 2014. - 31 iyulya.

60. O protivodeistvii korruptsii v Respublike Khakasiya: Zakon Respubliki Khakasiya ot 04.05.2009 №28-ZRKh (v red. ot 05.02.2016 №07-ZRKh) // Vestnik Khakasii. - 2009. - 8 maya.

61. O protivodeistvii korruptsii v Rostovskoi oblasti: oblastnoi zakon Rostovskoi oblasti ot 12.05.2009 №218-ZS (red. ot 23.06.2016 №545-ZS) // Nashe vremya. - 2009. - 13 maya.

62. O protivodeistvii korruptsii v Samarskoi oblasti: zakon Samarskoi oblasti ot 10.03.2009 №23-GD (v red. ot 19.05.2014 №57-GD) // Volzhskaya kommuna. - 2009. - 12 marta.

63. O protivodeistvii korruptsii v Ul'yanovskoi oblasti: zakon Ul'yanovskoi oblasti ot 20.07.2012 №89-ZO (v red. ot 01.07.2016 №94-ZO) // Ul'yanovskaya pravda. - 2012. - 24 iyulya.

64. O protivodeistvii korruptsii v Chechenskoi Respublike: zakon Chechenskoi Respubliki ot 21 maya 2009 goda №36-RZ (v red. ot 17.01.2016 №2-RZ) // Vesti respubliki. - 2009. - 10 iyunya.

65. O protivodeistvii korruptsii: federal'nyi zakon ot 25.12.2008 №273-FZ (v red. ot 15.02.2016 №24-FZ) // Sobranie zakonodatel'stva RF. - 2008. - №52 (ch. 1). - St.6228.

66. O realizatsii zakonodatel'stva o protivodeistvii korruptsii v otnoshenii lits, zameshchayushchikh dolzhnosti rukovoditelei gosudarstvennykh uchrezhdenii Yaroslavskoi oblasti: ukaz Gubernatora Yaroslavskoi oblasti ot 28.02.2013 №111 (v red. ot 07.04.2016 №185) // Dokument-Region. - 2013. - 5 marta.

67. O realizatsii zakonodatel'stva o protivodeistvii korruptsii $\mathrm{v}$ otnoshenii lits, zameshchayushchikh gosudarstvennye dolzhnosti Yaroslavskoi oblasti: ukaz Gubernatora Yaroslavskoi oblasti ot 31.01.2013 №46 (v red. ot 07.04.2016 №185) // Dokument-Region. - 2013. - 12 fevralya.

68. O sozdanii rabochei gruppy po provedeniyu vyborochnykh vyezdnykh proverok deyatel'nosti organov mestnogo samoupravleniya Respubliki Kalmykiya po protivodeistviyu korruptsii: rasporyazhenie Glavy Respubliki Kalmykiya ot 24.09.2010 №171-rg (v red. ot 19.12.2011 №231-rg) // Khal'mg unn. - 2010. - 29 sentyabrya.

69. Ob upravlenii kadrovoi politiki i protivodeistviya korruptsii administratsii Krasnodarskogo kraya: postanovlenie glavy administratsii (gubernatora) Krasnodarskogo kraya ot 21.12.2015 №1243 (v red. ot 16.05.2016 №310)// Ofitsial'nyi 
sait administratsii Krasnodarskogo kraya http://admkrai.krasnodar.ru, 21.12.2015.

70. Ob utverzhdenii Polozheniya o Departamente obshchestvennoi bezopasnosti goroda Sevastopolya: postanovlenie Pravitel'stva Sevastopolya ot 13.09.2016 №859-PP // Ofitsial'nyi sait Pravitel'stva Sevastopolya http://sevastopol.gov. $\mathrm{ru}, 14.09 .2016$.

71. Ob utverzhdenii polozheniya o poryadke provedeniya proverki, predusmotrennoi chast'yu 6 stat'i 12 Federal'nogo zakona ot 25 dekabrya 2008 goda №273-FZ "O protivodeistvii korruptsii": prikaz minekonomiki Nizhegorodskoi oblasti ot 11.04.2016 №79 // Nizhegorodskaya pravda. - 2016. - 2 iyulya.

72. Ob utverzhdenii Polozheniya o proverke dostovernosti i polnoty svedenii o dokhodakh, ob imushchestve i obyazatel'stvakh imushchestvennogo kharaktera, predstavlyaemykh grazhdanami, pretenduyushchimi na zameshchenie gosudarstvennykh dolzhnostei Respubliki Mordoviya, i litsami, zameshchayushchimi gosudarstvennye dolzhnosti Respubliki Mordoviya, i soblyudeniya ogranichenii litsami, zameshchayushchimi gosudarstvennye dolzhnosti Respubliki Mordoviya: ukaz Glavy Respubliki Mordoviya ot 05.02.2016 №27-UG // Izvestiya Mordovii. - 2016. - 9 fevralya;

73. Ob utverzhdenii polozheniya ob otdele protivodeistviya korruptsii upravleniya gosudarstvennoi grazhdanskoi sluzhby i kadrov Apparata Administratsii Nenetskogo avtonomnogo okruga: prikaz Apparata administratsii Nenetskogo avtonomnogo okruga ot 30.12.2014 №92.

74. Ob utverzhdenii Poryadka osushchestvleniya kontrolya za soblyudeniem zakonodatel'stva Rossiiskoi Federatsii o protivodeistvii korruptsii $\mathrm{v}$ gosudarstvennykh uchrezhdeniyakh Yamalo-Nenetskogo avtonomnogo okruga i organizatsiyakh, sozdannykh dlya vypolneniya zadach, postavlennykh pered ispolnitel'nymi organami gosudarstvennoi vlasti Yamalo-Nenetskogo avtonomnogo okruga, a takzhe za realizatsiei v etikh uchrezhdeniyakh i organizatsiyakh mer po profilaktike korruptsionnykh pravonarushenii: postanovlenie Gubernatora Yamalo-Nenetskogo avtonomnogo okruga ot 07.04.2016 №63-PG // Krasnyi Sever. - 2016. - 15 aprelya.

75. Ob utverzhdenii Poryadka uvedomleniya rabotodatelya o faktakh obrashcheniya $v$ tselyakh skloneniya rabotnika Gosudarstvennogo uchrezhdeniya-Permskogo regional'nogo otdeleniya Fonda sotsial'nogo strakhovaniya Rossiiskoi Federatsii k soversheniyu korruptsionnykh pravonarushenii, registratsii takikh uvedomlenii i organizatsii proverki soderzhashchikhsya v nikh svedenii: prikaz GU-Permskogo regional'nogo otdeleniya FSS RF ot 15.01.2013 №16;

76. Ob utverzhdenii poryadka uvedomleniya rabotodatelya o faktakh obrashcheniya $\mathrm{v}$ tselyakh skloneniya rabotnika, zanimayushchego dolzhnost', ne otnosyashchuyusya $\mathrm{k}$ dolzhnostyam munitsipal'noi sluzhby, munitsipal'nym dolzhnostyam administratsii gorodskogo poseleniya Krasnogorsk, k soversheniyu korruptsionnykh pravonarushenii: rasporyazhenie glavy gorodskogo poseleniya Krasnogorsk Krasnogorskogo munitsipal'nogo raiona Moskovskoi oblasti ot 09.02.2016 №27 // Krasnogorskie vesti. - 2016. - 22 marta.

77. Pravovoe regulirovanie gosudarstvennogo kontrolya: monografiya / otv. red. A.F. Nozdrachev. - M., 2012. - 480 s.

78. Pravovoi mekhanizm gosudarstvennogo kontrolya i nadzora: osobennosti otraslevogo regulirovaniya: monografiya / Pod obshch. red. O.Yu. Bakaeva. - M., 2013. - 256 s.

79. Protivodeistvie korruptsii v sub"ektakh Rossiiskoi Federatsii: nauchno-prakticheskoe posobie / L.V. Andrichenko, O.A. Belyaeva, V.I. Vasil'ev i dr.; pod red. T.Ya. Khabrievoi. - M., 2013. - 236 c.

80. Savenko O.E. Kontrol'naya funktsiya gosudarstvennykh organov: dis. ... kand. yurid. nauk. - Saratov, 2004 . - 195 s.

81. Svodnyi otchet o sostoyanii korruptsii i realizatsii mer antikorruptsionnoi politiki v Respublike Tatarstan v 2013 godu. Kazan', 2004. - $126 \mathrm{~s}$.

82. Simbireva E.V. Antikorruptsionnyi kontrol' v sisteme gosudarstvennoi sluzhby // Modernizatsionnyi vektor razvitiya nauki v XXI veke: traditsii, novatsii, preemstvennost' sbornik nauchnykh statei po itogam mezhdunarodnoi nauchnoprakticheskoi konferentsii. SPb., 2016. S. 288-291.

83. Sleptsov M.G. Pravovoe regulirovanie gosudarstvennogo kontrolya v krayakh i oblastyakh - sub"ektakh Rossiiskoi Federatsii: avtoref. dis. ... kand. yurid. nauk. - M., 1999.

84. Solov'eva E.P., Tsybakov D.L. Kontrol' za raskhodami gosudarstvennykh sluzhashchikh kak instrument protivodeistviya korruptsii // Ekonomika i sotsium. - 2014. - №4-4 (13). - S.993-996.

85. Tarasov A.M. Gosudarstvennyi kontrol' v Rossii: monografiya. - M., 2008. - 644 s.

86. Uliz'ko K.A. Kontrol' imushchestvennogo polozheniya lits, zameshchayushchikh (zanimayushchikh) dolzhnosti, ustanovlennykh zakonodatel'stvom o protivodeistvii korruptsii // Munitsipal'naya sluzhba: pravovye voprosy. - 2016. №2. - S.3-5.

87. Umanskaya V.P. Gosudarstvennyi kontrol' i nadzor za soblyudeniem zakonodatel'stva o gosudarstvennoi grazhdanskoi sluzhbe: avtoref. dis. ... kand. yurid. nauk. - M., 2007. - 18 s.

88. Khabrieva T.Ya. Korruptsiya i pravo: doktrinal'nye podkhody k postanovke problemy // Zhurnal rossiiskogo prava. 2012.-№6. - S.5-17.

89. Channov S.E. Zakon o kontrole za raskhodami chinovnikov: voprosy effektivnosti // Gosudarstvennyi audit. Pravo. Ekonomika. - 2013. - №2. - S.102-108.

90. Shedii M.V. Korruptsiya kak sotsial'noe yavlenie: teoretiko-metodologicheskie aspekty issledovaniya: Monografiya. - Orel, 2011. - $180 \mathrm{~s}$.

91. Shedii M.V. Sotsial'nye determinanty korruptsii v rossiiskom obshchestve: Monografiya. - Orel, $2012 .-148 \mathrm{~s}$.

92. Shurukhanova D.N. Kontrol' imushchestvennogo polozheniya kak mera po protivodeistviyu korruptsii // NB: Administrativnoe pravo i praktika administrirovaniya. - 2013. - №6. - S.83-98.

93. Bikeev I.I., Magizov R.R. Retsenziya na monografiyu: Kabanov P.A. Antikorruptsionnyi monitoring v sub"ektakh Rossiiskoi Federatsii: voprosy teorii i praktiki pravovogo regulirovaniya. - Nizhnii Novgorod: Nizhegorodskaya akademiya MVD Rossii, 2015. - 181 s. // NB: Administrativnoe pravo i praktika administrirovaniya. - 2016. - 3. - C. 26 - 39 . DOI: 10.7256/2306-9945.2016.3.19010. URL: http://www.e-notabene.ru/al/article_19010.html 